\title{
Comparison of the nutritional content of products, with and without nutrient claims, targeted at children in Brazil
}

\author{
Vanessa Mello Rodrigues ${ }^{1,2}$, Mike Rayner ${ }^{2}$, Ana Carolina Fernandes ${ }^{1}$, Renata Carvalho de Oliveira ${ }^{1}$, \\ Rossana Pacheco da Costa Proença ${ }^{1}$ and Giovanna Medeiros Rataichesck Fiates ${ }^{1 *}$ \\ ${ }^{1}$ Nutrition Graduate Programme (Programa de Pós-Graduação em Nutrição), Nutrition in Foodservice Research Centre \\ (NUPPRE), Federal University of Santa Catarina (UFSC), Trindade University Campus, 88040-970, Florianópolis, SC, Brazil \\ ${ }^{2}$ Nuffield Department of Population Health, British Heart Foundation Centre on Population Approaches for \\ Non-Communicable Disease Prevention, University of Oxford, Old Road Campus, Headington, OX1 7LF, Oxford, UK
}

(Submitted 15 September 2015 - Final revision received 1 February 2016 - Accepted 3 February 2016 - First published online 4 April 2016)

\section{Abstract}

Many children's food products highlight positive attributes on their front-of-package labels in the form of nutrient claims. This cross-sectional study investigated all retailed packaged foods ( $n$ 5620) in a major Brazilian supermarket, in order to identify the availability of products targeted at children, and to compare the nutritional content of products with and without nutrient claims on labels. Data on energy, carbohydrate, protein, fibre, $\mathrm{Na}$ and total and SFA content, along with the presence and type of nutrient claims, were obtained in-store from labels of all products. Products targeted at children were identified, divided into eight food groups and compared for their nutritional content per $100 \mathrm{~g} / \mathrm{ml}$ and the presence of nutrient claims using the Mann-Whitney $U$ test $(P<0.05)$. Of the 535 food products targeted at children (9.5\% of all products), 270 (50.5\%) displayed nutrient claims on their labels. Children's products with nutrient claims had either a similar or worse nutritional content than their counterparts without nutrient claims. The major differences among groups were found in Group 8 (e.g. sauces and ready meals), in which children's products bearing nutrient claims had higher energy, carbohydrate, Na and total and SFA content per $100 \mathrm{~g} / \mathrm{ml}$ than products without nutrient claims $(P<0.05)$. This suggests that, to prevent misleading parents who are seeking healthier products for their children, the regulation on the use of nutrient claims should be revised, so that only products with appropriate nutrient profiles are allowed to display them.

\section{Key words: Labelling: Food products: Packages: Children: Nutrition}

Brazil, similar to most developing countries, has experienced an increasing trend towards purchasing and consuming processed food $_{\text {products }}{ }^{(1)}$, as well as rising rates of overweight, obesity and other non-communicable diseases. The increase in obesity in the country has followed the classical demographic spread from adults to adolescents and then to children ${ }^{(2)}$. In 2013, $56.9 \%$ of Brazilian adults were overweight and about $20.8 \%$ were obese $^{(3)}$. From 1974 to 2009 , the prevalence of overweight in children (6-11 years) significantly increased among both males $(8 \cdot 3-33 \cdot 8 \%)$ and females $(7 \cdot 2-30 \cdot 0 \%)^{(2)}$, whereas obesity rates among children (5-9 years) reached $15 \cdot 0 \%{ }^{(4)}$. Brazilian overweight and obesity rates are higher than global averages, ranking fifth among all countries in terms of number of obese people $^{(5)}$. It has been estimated that by 2050 the healthcare costs attributable to obesity and overweight-related diseases in Brazil will double from $\$ 5.8$ billion to $\$ 10 \cdot 1$ billion, and that nearly $70 \%$ of Brazilian adults could be overweight if the present trends are sustained ${ }^{(6)}$.

Nutrition labelling is one of the strategies by the WHO to prevent and control the burden of non-communicable diseases $^{(7)}$, and it is designed to inform consumers about the nutritional properties of food as well as to help them make healthier food choices ${ }^{(8)}$. Indeed, studies have shown that those who read food labels more frequently eat healthier diets than those who read the labels less frequently ${ }^{(9,10)}$. However, if consumers do not understand the vocabulary or layout used to display nutritional information ${ }^{(11)}$, this can lead to confusion about which foods to choose.

One particular study revealed that consumers prefer shorter and simpler messages ${ }^{(12)}$ - a format generally used by manufacturers for presenting claims on their food labels. A recent study suggested taxonomy for food labelling ${ }^{(13)}$, based on a review of guidelines from international governing bodies and legislative documents, by dividing the components of food labelling into 'information' and 'claims'. The 'information' items comprise 'nutrition labelling' (e.g. nutrient declaration) and 'other information' (e.g. ingredients), whereas the 'claims' are categorised into 'nutrition claims' (health-related ingredient claims and nutrient claims), 'health claims' (e.g. function claims) or 'other claims'.

It has been indicated that claims have both the potential to inform consumers and to mislead them, depending on the 
information that is highlighted and the kind of product displaying this information ${ }^{(14)}$. Accordingly, some countries have legislations aimed at regulating the use of claims, for example making the nutrient declaration mandatory when the product displays a claim ${ }^{(15)}$. In Brazil, displaying a nutrient declaration has been mandatory since 2001, but there is little scientific discussion in the country about the components of food labelling. A regulation establishing parameters for the use of nutrient claims was published by the Brazilian National Health Surveillance Agency (Resolution no. 54/2012) and incorporated into the Mercosur agreement (Resolution no. 01/2012) ${ }^{(16)}$. However, this regulation does not consider the entire nutrient composition of foods. This allows, for instance, a high-sugar/high-Na product to display a nutrient claim on its label. In the USA ${ }^{(17)}$, if a food product displaying a nutrition claim has high levels of SFA or trans-fats, sugars or $\mathrm{Na}$, it must also include a statement disclosing that the food contains excessive amounts of these components. Australia and New Zealand have agreed on the use of a nutrient profile model for determining the eligibility of products in terms of making a health claim, but this has not been applied to nutrition claims ${ }^{(18)}$. In the European Union, discussion is under way on whether foods will need to have an appropriate nutrient profile in order to display nutrition and health claims ${ }^{(19)}$

Usually, claims are displayed in a prominent position on the package, and are used as an advertising strategy to promote food sales ${ }^{(14,20)}$. This happens because, although it has an informative role, the emphasis on attributes considered as positive on labels can attribute a health halo effect to the food, which means the perception that a food product is healthy is based on one or more 'healthy' attributes of that food ${ }^{(21)}$. In addition, claims can be included on any packaged food if in accordance with the quantities stipulated by the legislation (e.g. according to Resolution no. 54/2012, the nutrient claim 'low SFA' can be used if a portion of $100 \mathrm{~g}$ or $100 \mathrm{ml}$ of the food/ beverage contains $<1.5 \mathrm{~g}$ of SFA). This means that food packages with persuasive strategies aimed at children (e.g. cartoon characters), which are often of low nutritional value and very palatable ${ }^{(22)}$, could also display such claims. The marketing of high-energy and low-nutrient foods is one of the factors contributing to an obesogenic environment, and the presence of nutrition claims on these types of food products could mislead consumers and boost their sales even further ${ }^{(23)}$.

Studies on the availability of food products with nutrition claims in supermarkets have revealed that the prevalence was $50 \%$ in the $\mathrm{USA}^{(24)}, 36 \%$ in Australia $^{(25)}, 66 \%$ in Spain ${ }^{(26)}$, $13 \%$ in Turkey ${ }^{(27)}, 47 \%$ in Ireland ${ }^{(28)}$ and $29 \%$ in the $\mathrm{UK}^{(29)}$. However, none of these studies investigated claims on food products of children. After a search on the databases Scopus and Scielo in June 2015, with the search terms 'nutrition/ nutrient claim', 'label' and 'food', two studies particularly related to nutrition claims on children's food products were identified. In those two studies, however, only a few food categories were investigated: nutritional quality of children's breakfast cereals with nutrition claims in the USA $(n 161)^{(30)}$, and comparison of yogurts, cereal bars and ready meals aimed at children ( $n$ 174) and adults $\left(n\right.$ 262) in the $\mathrm{UK}^{(31)}$. No study was identified that focused on the use of nutrition claims on Brazilian food products for children.
Therefore, considering the burden of diet-related diseases, the limited evidence that claims can lead to better food choices and the lack of data on the availability and composition of food displaying nutrition claims in Brazil, this study aimed to investigate the food labelling data for all retailed packaged food in one of the ten largest supermarket chains in Brazil. We attempted to identify the availability of products targeted at children and compare their nutritional content in terms of the presence of nutrient claims on labels.

\section{Methods}

\section{Study design}

This was a cross-sectional study that investigated all retailed packaged food products available in a large supermarket in Brazil. The supermarket was chosen deliberately and belongs to one of the ten largest Brazilian chain stores, according to the Brazilian Supermarket Association, with twenty-seven stores throughout the country. Therefore, most of the products sold in this store are wellknown food and drink brands, and represent those sold in other large supermarket chain stores throughout Brazil.

All packaged food products that met criteria established by the Brazilian regulation on food labelling (no. 360/2003) were included in the audit ${ }^{(32)}$. Products not included in the study were those covered by different regulations (i.e. food for babies and toddlers) or those that did not require mandatory nutritional labelling (i.e. bakery products produced, packaged and labelled in-store, or meat and cheese products cut, packed and labelled in-store) ${ }^{(33)}$. The supermarket manager gave written consent for the research.

\section{Data collection}

Data were gathered over a 3-month period (October to December 2013) in the city of Florianópolis/SC, southern Brazil. Information on identification, origin, nutritional values (energy, carbohydrate, protein, total fat, SFA, trans-fat, fibre and $\mathrm{Na}$ per serving), size of serving and the presence and type of nutrient claims were obtained in-store from labels of all available products. These data were then fed into electronic data collection forms, which were created using Epi Collect Plus software and installed on tablet computers. Information on the packages of identical products of different sizes was recorded separately, because sometimes their servings and nutritional values differed. All food labels were photographed in-store to allow identification of food products that were being marketed for children. All data collectors received training and participated in a field test of the instrument 1 month before data collection in a different supermarket: they were asked to feed the electronic forms with information from fifteen food products from different food groups, individually and with no help, and the information was further checked by the main researcher. Subsequently, the data were examined, difficulties and inconsistencies were identified, and extra training was provided.

\section{Variable computation}

Data collected were transferred directly from the tablet computers to an online database at the end of each collection day. 
The database with all the data was exported to a Microsoft Excel spreadsheet. Each food product was coded with a number as it was entered into the database (creating its food product number), and later each image in the database was renamed according to the corresponding food product number. If there were more than one image of a product, letters were used after the food product number.

For quality control purposes, information from the database relating to two nutrient declaration questions (energy in kilocalories per serving and $\mathrm{Na}$ content in milligrams per serving) and to the presence of nutrient claims was compared with the information available on the photographs for $5 \%$ of the foods analysed ( $n$ 281). According to the $\kappa$ test, there was a high degree of inter-variable agreement: $99.7 \% \quad(\kappa=0.99)$ for energy, $99.9 \%(\kappa=0.99)$ for $\mathrm{Na}$ content and $99.6 \%(\kappa=0.99)$ for nutrient claims $(P<0 \cdot 05)$. After the test, the inconsistencies identified in the database information among these 281 foods were rectified according to the information available in the pictures.

\section{Sampling: definition of food products targeted at children}

Data from 5620 food products were obtained from the audit, and all packaging images from the database were analysed. Products were defined as being targeted towards children if at least one of the following strategies was present: words and phrases such as 'child' or 'ideal snack for your child'; specified age ranges (e.g. 2-9 years); cartoon, television (TV) series or film characters; own-brand characters; child celebrities; images of animals or creatures; games or hobbies; colours or shapes that appeal to children (e.g. brightly coloured drinks or alphabet soup); or free gifts ${ }^{(31,34-36)}$

Two researchers were involved in the identification of products aimed at children. A third researcher was consulted for those products for which there was no agreement about whether the marketing strategies were targeted at children.

Of the total number of food products identified in the audit, $535(9.5 \%)$ had used at least one of the marketing strategies listed above and were considered as having targeted children, constituting our sample.

\section{Classification of food groups}

Each of the 535 food products targeted at children was categorised into one of the eight groups identified by the Brazilian and Mercosur Regulation ${ }^{(33)}$, which classifies similar foods according to their main source of energy. The groups were as follows: (1) baking goods, breads, cereals, legumes, roots, tubers and related products; (2) fresh and canned vegetables; (3) fruits, juices, syrups and drink mixes; (4) milk and dairy products; (5) meat and eggs; (6) oils, fats and nuts; (7) sugars and products in which carbohydrates and fats are the main energy sources; and (8) gravies, sauces, ready-made seasonings, broths, soups and ready-to-eat dishes.

\section{Nutrient claims}

Our analysis included all nutrient claims that could be observed on any surface of the packaging that is visible to the consumer

\begin{tabular}{|c|c|c|}
\hline Type of nutrient claim & Term used & Types of nutrients claimed \\
\hline \multirow{5}{*}{$\begin{array}{l}\text { Reduced amount or } \\
\text { absence }\end{array}$} & Low & \multirow{2}{*}{$\begin{array}{l}\text { Energy, total fat, SFA, cholesterol, } \\
\text { sugar, } \mathrm{Na}\end{array}$} \\
\hline & Reduced/light/lite & \\
\hline & Free & $\begin{array}{l}\text { Energy, total fat, SFA, trans-fat, } \\
\text { cholesterol, sugar, } \mathrm{Na}\end{array}$ \\
\hline & Very low & $\mathrm{Na}$ \\
\hline & With no added & Sugar, salt \\
\hline \multirow{3}{*}{$\begin{array}{c}\text { Increased amount or } \\
\text { presence }\end{array}$} & Source of & \multirow{2}{*}{$\begin{array}{c}n-3, n-6 \text { and } n-9 \text { fatty } \\
\text { acids, proteins, fibre, vitamins, minerals }\end{array}$} \\
\hline & High & \\
\hline & Increased & Proteins, fibre, vitamins, minerals \\
\hline
\end{tabular}

Fig. 1. Classification of nutrient claims (reduced amount/absence or increased amount/presence) according to terms used and types of nutrients claimed. Adapted from National Health Surveillance Agency ${ }^{(16)}$.

(comprising all different formats, e.g. single words, phrases, sentences, symbols, logos or images). The nutrient claims identified on the food products aimed at children were grouped by their nature: 'reduced amount or absence' or 'increased amount or presence', as shown in Fig. 1.

\section{Statistical analysis}

Descriptive variables relating to the number of food products marketed at children overall and per food group, as well as marketing strategies and nutrient claims identified, are presented by absolute and relative frequencies. The nutritional composition relating to energy, carbohydrates, total and SFA, proteins, fibre and $\mathrm{Na}$ was compared between food products, with and without nutrient claims, targeted at children. Considering the non-normal distribution of the nutritional composition data, verified using the Shapiro-Wilk test, analyses were compared using the Mann-Whitney $U$ test ( $P$ value $<0.05)$. The statistical package Stata version 11.0 (StataCorp LP) was used for the analyses.

\section{Results}

Among the 535 food products targeted at children identified at the supermarket, 696 marketing strategies aimed at children were identified. Approximately $25.0 \%$ of the products had used two or more of these marketing strategies on the same food package, mainly relating to images: cartoon, TV series and film characters (48.8\%) and own-brand characters (34.4\%).

Fig. 2 shows the distribution of food products according to the groups proposed by Regulation 359/2003, as well as the different food products identified in the supermarket per group. More than half of all the food products identified as targeting children were from Group 7, which included products such as sweets and sweetened carbonated drinks, whereas fruit and vegetable groups (Groups 2 and 3) represented only $3 \%$ of the total food targeted at children.

Around half of the food products marketed for children (270; $50.5 \%$ ) displayed at least one nutrient claim. Usually, the products claimed more than one component, with an average of $4 \cdot 1$ claims per product. The majority of nutrient claims related to increased amounts or to the presence of vitamins $(65.5 \%)$ and minerals (20.4\%). The most common claims declared an increase or the presence of vitamins $\mathrm{A}, \mathrm{B}_{2}, \mathrm{C}, \mathrm{B}_{6}$ and Fe. Table 1 


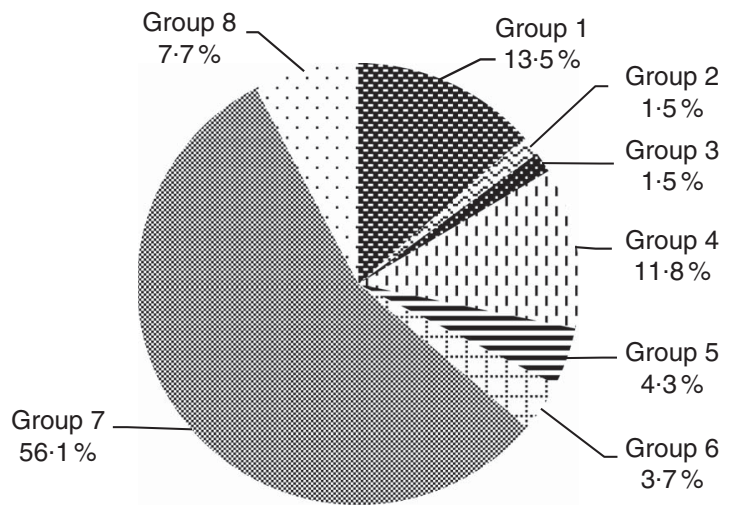

Fig. 2. Distribution of food products targeted at children, identified according to the Brazilian and Mercosur Regulation food groups ${ }^{(33)}$ (n 535). Group 1, "baking goods, breads, cereals, legumes, roots, tubers and related products': dried rice, dried pasta, pre-fried and frozen tubers, savoury and/or whole-grain biscuits, breakfast cereals, granola, plan bread, custard powder mix, cake mix. Group 2, 'fresh and canned vegetables': tomato sauce, sweetcorn, cherry tomatoes, baby carrots. Group 3, 'fruits, juices, syrups and drink mix': fruit juice, nectars, apples. Group 4, 'milk and dairy products': milky drinks, fermented milk, yoghurt, dairy dessert, pudding powder mix. Group 5, 'meats and eggs': meatballs, burgers, sausages, bologna, paté, eggs, chicken nuggets, fish fingers. Group 6, 'oils, fats and nuts': bacon, spreads, coconut milk, peanuts. Group 7, 'sugars and products in which carbohydrates and fats are the main energy sources': sweet spreads, powder drinks, honey, syrups, gelatine powder mix, candies, gum, chocolate, icecream, sweetened carbonated drinks, sweet biscuits, crisps, puffs chips. Group 8 , 'gravies, sauces, ready-made seasonings, broths and ready-to-eat dishes': ketchup, lasagne, salt dough pie, pizza, noodles. shows the frequency of different nutrient claims identified on the products.

Tables 2 and 3 compare the energy and content of carbohydrates, total fat, SFA, proteins, fibre and $\mathrm{Na}$ between food products, with and without nutrient claims, targeted at children. In general, there were a few significant differences between the nutrient levels of foods with and without nutrient claims. However, for $\mathrm{Na}$, the analysis showed that children's food products labelled with nutrient claims contained a higher median of $\mathrm{Na}$ than those without nutrient claims in Group 1, 'baking goods, breads, cereals, legumes, roots and tubers' (394.2 mg/100 g higher in products with claims); Group 7, 'sugars, sweets, confectioneries, biscuits, snacks and soft drinks' $(172.3 \mathrm{mg} / 100 \mathrm{~g}$ higher in products with claims); and Group 8, 'gravies, sauces, ready-made seasonings, broths and ready meals' $(1327.4 \mathrm{mg} / 100 \mathrm{~g}$ higher in products with claims). A higher amount of $\mathrm{Na}$ in children's products without nutrient claims was observed only in food products of Group 4 ('milk and dairy products'), which showed a median of $14.5 \mathrm{mg}$ less $\mathrm{Na}$ per $100 \mathrm{~g}$.

The major differences were observed in foods from Group 8, in which ketchup, lasagne, salt dough pie, pizza and noodles with and without nutrient claims targeted at children were compared. In this group, foods displaying nutrient claims had higher levels of mean energy $(1850 \cdot 2 \mathrm{~kJ} / 100 \mathrm{~g}(442 \cdot 4 \mathrm{kcal} / 100 \mathrm{~g})$ compared with $633.0 \mathrm{~kJ} / 100 \mathrm{~g}(151.3 \mathrm{kcal} / 100 \mathrm{~g})$ in those

Table 1. Distribution of nutrient claims on food products targeted at children, as defined by the Brazilian and Mercosur Regulation food groups ${ }^{(33)}$ (Numbers and percentages)

\begin{tabular}{|c|c|c|c|c|c|c|c|c|c|c|}
\hline & \multicolumn{8}{|c|}{ Groups } & \multicolumn{2}{|c|}{ Total } \\
\hline & G1 & G2 & G3 & G4 & G5 & G6 & G7 & G8 & $n$ & $\%$ \\
\hline \multicolumn{11}{|l|}{ Reduction/absence claims } \\
\hline Energy & - & - & - & 1 & - & 4 & 1 & - & 6 & 0.5 \\
\hline Total fat & 2 & - & - & 1 & 1 & - & 15 & - & 19 & 1.7 \\
\hline SFA & 3 & - & - & - & - & - & 5 & - & 8 & 0.7 \\
\hline Trans-fat & 16 & - & - & 3 & 5 & - & 29 & 3 & 56 & 5.0 \\
\hline Cholesterol & 7 & - & - & - & - & 1 & 12 & - & 20 & 1.8 \\
\hline $\mathrm{Na}$ & - & - & - & - & 1 & - & 13 & - & 14 & 1.3 \\
\hline Sugar & 3 & - & 2 & 3 & - & 1 & 5 & - & 14 & $1 \cdot 3$ \\
\hline \multicolumn{11}{|l|}{ Increase/presence claims } \\
\hline \multicolumn{11}{|l|}{ Minerals } \\
\hline $\mathrm{Ca}$ & 5 & - & - & 19 & - & - & 46 & - & 70 & $6 \cdot 3$ \\
\hline $\mathrm{Fe}$ & 16 & - & - & 10 & 7 & - & 52 & 1 & 86 & $7 \cdot 7$ \\
\hline $\mathrm{Mg}$ & - & - & - & 1 & - & - & - & - & 1 & $0 \cdot 1$ \\
\hline $\mathrm{P}$ & - & - & - & 4 & - & - & - & - & 4 & 0.4 \\
\hline $\mathrm{Zn}$ & 13 & - & - & 12 & 7 & - & 32 & 1 & 65 & $5 \cdot 9$ \\
\hline \multicolumn{11}{|l|}{ Vitamins } \\
\hline A & 11 & 1 & 5 & 11 & - & - & 73 & - & 101 & $9 \cdot 1$ \\
\hline $\mathrm{B}_{1}$ & 12 & - & - & 10 & 11 & - & 41 & 4 & 78 & $7 \cdot 0$ \\
\hline $\mathrm{B}_{2}$ & 16 & - & - & 10 & 11 & - & 52 & 4 & 93 & 8.4 \\
\hline $\mathrm{B}_{3}$ & 15 & - & 5 & 2 & - & - & 42 & 3 & 67 & $6 \cdot 0$ \\
\hline $\mathrm{B}_{5}$ & 6 & - & - & - & - & - & 7 & - & 13 & $1 \cdot 2$ \\
\hline $\mathrm{B}_{6}$ & 15 & - & 5 & 10 & 11 & - & 44 & 4 & 89 & $8 \cdot 0$ \\
\hline $\mathrm{B}_{9}$ & 14 & - & - & 2 & - & - & 24 & - & 40 & $3 \cdot 6$ \\
\hline$B_{12}$ & 10 & - & 5 & 1 & 11 & - & 28 & 1 & 56 & $5 \cdot 0$ \\
\hline $\mathrm{C}$ & 10 & - & 5 & 7 & - & - & 69 & - & 91 & $8 \cdot 2$ \\
\hline D & 3 & - & 5 & 31 & - & - & 21 & - & 60 & 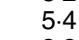 \\
\hline $\mathrm{E}$ & - & 1 & 5 & 10 & - & - & 20 & - & 36 & $3 \cdot 2$ \\
\hline Fibre & 5 & 1 & - & - & - & - & 10 & - & 16 & 1.4 \\
\hline Protein & 2 & - & - & - & - & - & 5 & - & 7 & 0.6 \\
\hline Total of NC identified & 184 & 3 & 37 & 148 & 65 & 6 & 646 & 21 & 1110 & $100 \cdot 0$ \\
\hline Total of products with $\mathrm{NC}^{\star}$ & 36 & 1 & 7 & 38 & 14 & 10 & 157 & 7 & 270 & 50.5 \\
\hline
\end{tabular}

NC, nutrient claims; G1, baking goods, breads, cereals, legumes, roots, tubers and related products; G2, fresh and canned vegetables; G3, fruits, juices, syrups and drink mix; G4, milk and dairy products; G5, meats and eggs; G6, oils, fats and nuts; G7, sugars and products in which carbohydrates and fats are the main energy sources; G8, gravies, sauces, ready-made seasonings, broths and ready-to-eat dishes.

* A food product can display more than one NC. 
Table 2. Comparison of energy, carbohydrate, total fat and SFA per $100 \mathrm{~g}$ of food products targeted at children labelled and not labelled with nutrient claims ${ }^{(33)}$ (Numbers, medians and interquartile ranges (IQR))

\begin{tabular}{|c|c|c|c|c|c|c|c|c|c|c|c|c|c|c|c|c|c|c|}
\hline \multirow[b]{2}{*}{ Categories } & \multirow[b]{2}{*}{$n$} & \multicolumn{2}{|c|}{ Energy (kcal) } & \multicolumn{2}{|c|}{ Energy (kJ) } & \multirow[b]{2}{*}{$P$} & \multirow[b]{2}{*}{$n$} & \multicolumn{2}{|c|}{ Carbohydrate (g) } & \multirow[b]{2}{*}{$P$} & \multirow[b]{2}{*}{$n$} & \multicolumn{2}{|c|}{ Total fat (g) } & \multirow[b]{2}{*}{$P$} & \multirow[b]{2}{*}{$n$} & \multicolumn{2}{|c|}{ SFA (g) } & \multirow[b]{2}{*}{$P$} \\
\hline & & Median & IQR & Median & IQR & & & Median & IQR & & & Median & IQR & & & Median & IQR & \\
\hline \multicolumn{19}{|l|}{ Group 1} \\
\hline Without NC & 36 & 354.0 & $333.0-363.7$ & $1481 \cdot 1$ & $1393 \cdot 2-1521 \cdot 7$ & \multirow[t]{2}{*}{0.517} & 36 & $73 \cdot 1$ & $52 \cdot 5-79 \cdot 2$ & \multirow{2}{*}{0.718} & 33 & 1.6 & $1.0-7 \cdot 0$ & \multirow[t]{2}{*}{0.337} & 33 & 0.4 & $0.0-1 \cdot 6$ & \multirow[t]{2}{*}{0.237} \\
\hline With NC & 36 & $363 \cdot 3$ & $293.0-376 \cdot 7$ & $1520 \cdot 0$ & $125 \cdot 5-279.02$ & & 36 & $66 \cdot 7$ & $53 \cdot 2-82 \cdot 5$ & & 35 & $2 \cdot 4$ & $1 \cdot 2-6 \cdot 2$ & & 35 & 0.8 & $0.0-1 \cdot 7$ & \\
\hline \multicolumn{19}{|l|}{ Group 2} \\
\hline Without NC & 7 & $43 \cdot 2$ & $30 \cdot 0-66 \cdot 7$ & $180 \cdot 7$ & $125 \cdot 5-279 \cdot 0$ & \multirow[t]{2}{*}{0.377} & 7 & $10 \cdot 4$ & $7 \cdot 6-13.8$ & \multirow{2}{*}{0.185} & 6 & 0.0 & $0.0-0.0$ & \multirow[t]{2}{*}{0.683} & 6 & 0.0 & $0.0-0.0$ & \multirow[t]{2}{*}{0.683} \\
\hline With NC & $1 \dagger$ & $66 \cdot 6$ & - & 278.6 & - & & $1 \dagger$ & $14 \cdot 0$ & - & & $1 \dagger$ & 0.0 & - & & $1 \dagger$ & 0.0 & - & \\
\hline \multicolumn{19}{|l|}{ Group 3} \\
\hline Without NC & $1 \dagger$ & $52 \cdot 0$ & - & 217.5 & - & \multirow[t]{2}{*}{0.450} & $1 \dagger$ & $15 \cdot 0$ & - & \multirow[t]{2}{*}{0.078} & $1 \dagger$ & 0.3 & - & - & $1 \dagger$ & 0.0 & - & - \\
\hline With NC & 7 & 39.0 & $39 \cdot 0-54 \cdot 0$ & $163 \cdot 1$ & $163 \cdot 2-225 \cdot 9$ & & 7 & 9.5 & $9.5-13.5$ & & - & - & & & - & - & & \\
\hline Group 4 & & & & & & & & & & & & & & & & & & \\
\hline Without NC & 25 & $82 \cdot 3$ & $75 \cdot 5-140 \cdot 0$ & $344 \cdot 3$ & $315 \cdot 9-585.7$ & 0.221 & 25 & $14 \cdot 7$ & $13 \cdot 1-20 \cdot 8$ & 0.211 & 20 & 2.5 & $1 \cdot 8-4.2$ & 0.224 & 20 & 1.6 & $1 \cdot 1-3 \cdot 2$ & 0.195 \\
\hline With NC & 38 & $82 \cdot 1$ & $68 \cdot 0-111 \cdot 1$ & 343.5 & $284.5-464 \cdot 8$ & & 38 & $14 \cdot 3$ & $12 \cdot 5-15 \cdot 8$ & & 36 & $2 \cdot 3$ & $1.0-3.0$ & & 36 & 1.5 & $0.6-2.0$ & \\
\hline Group 5 & & & & & & & & & & & & & & & & & & \\
\hline Without NC & 9 & 203.8 & $167 \cdot 3-215 \cdot 0$ & 343.5 & 699.9-899.6 & 0.729 & 9 & $6 \cdot 0$ & $1.6-12.5$ & 0.297 & 9 & $10 \cdot 0$ & $9 \cdot 9-15 \cdot 0$ & 0.467 & 9 & 4.0 & $4 \cdot 0-5 \cdot 2$ & $0.031^{*}$ \\
\hline With NC & 14 & 204.5 & $171 \cdot 0-216 \cdot 1$ & 855.6 & $715 \cdot 4-904 \cdot 2$ & & 14 & $17 \cdot 0$ & $5 \cdot 5-19 \cdot 2$ & & 14 & 9.2 & $8.5-14.0$ & & 14 & 2.6 & $1.5-4.0$ & \\
\hline Group 6 & & & & & & & & & & & & & & & & & & \\
\hline Without NC & 10 & 482.9 & $253 \cdot 3-600 \cdot 0$ & $2020 \cdot 4$ & $1059 \cdot 8-2510 \cdot 4$ & 0.675 & 7 & 18.5 & $0.0-31 \cdot 7$ & 0.662 & 10 & 39.5 & $20 \cdot 0-60 \cdot 0$ & 0.731 & 10 & 29.8 & $18 \cdot 0-46 \cdot 0$ & 0.422 \\
\hline With NC & 10 & $574 \cdot 2$ & $126 \cdot 7-720 \cdot 0$ & $2402 \cdot 4$ & $530 \cdot 12-3012 \cdot 5$ & & 5 & 0.0 & $0.0-20.0$ & & 10 & 52.5 & $10 \cdot 0-80 \cdot 0$ & & 10 & $20 \cdot 0$ & $9 \cdot 3-20 \cdot 0$ & \\
\hline Group 7 & & & & & & & & & & & & & & & & & & \\
\hline Without NC & 143 & $396 \cdot 7$ & $320 \cdot 0-488 \cdot 9$ & $1659 \cdot 7$ & $1338 \cdot 9-2045 \cdot 6$ & 0.218 & 143 & $65 \cdot 0$ & $52 \cdot 0-90 \cdot 0$ & 0.421 & 95 & 15.9 & $3 \cdot 0-27 \cdot 6$ & 0.140 & 87 & 4.5 & $1 \cdot 5-15 \cdot 2$ & 0.062 \\
\hline With NC & 157 & $380 \cdot 0$ & $355.0-460.0$ & $1589 \cdot 9$ & $1485 \cdot 3-1924 \cdot 6$ & & 157 & 68.0 & $55 \cdot 0-76 \cdot 7$ & & 119 & $16 \cdot 2$ & $0.3-20.0$ & & 118 & $6 \cdot 1$ & $0.0-8.4$ & \\
\hline Group 8 & & & & & & & & & & & & & & & & & & \\
\hline Without NC & 34 & $151 \cdot 3$ & $127 \cdot 3-248 \cdot 0$ & 633.0 & $532 \cdot 6-1037 \cdot 6$ & $0.003^{*}$ & 34 & $13 \cdot 0$ & $11 \cdot 4-26 \cdot 0$ & & 33 & 8.0 & $5 \cdot 5-10 \cdot 3$ & $0.009^{*}$ & 33 & 3.4 & $2 \cdot 7-4 \cdot 6$ & $0.008^{*}$ \\
\hline With NC & 7 & $442 \cdot 4$ & $438 \cdot 7-447 \cdot 1$ & 1851.0 & $1835 \cdot 5-1870 \cdot 6$ & & 7 & $60 \cdot 6$ & $60 \cdot 0-61 \cdot 2$ & $<0.001^{*}$ & 7 & 17.9 & $16 \cdot 1-18 \cdot 8$ & & 7 & 8.0 & $6 \cdot 1-8 \cdot 8$ & \\
\hline
\end{tabular}

NC, nutrient claim; Group 1, baking goods, breads, cereals, legumes, roots, tubers and related products; Group 2, fresh and canned vegetables; Group 3, fruits, juices, syrups and drink mix; Group 4, milk and dairy products; Group 5, meats and eggs; Group 6, oils, fats and nuts; Group 7, sugars and products in which carbohydrates and fats are the main energy sources; Group 8, gravies, sauces, ready-made seasonings, broths and ready-to-eat dishes.

† The IQR were run for all groups, except for groups with only one food product. 
Table 3. Comparison of protein, fibre and sodium per $100 \mathrm{~g}$ of food products targeted at children labelled and not labelled with nutrient claims ${ }^{(33)}$ (Numbers, medians and interquartile ranges (IQR))

\begin{tabular}{|c|c|c|c|c|c|c|c|c|c|c|c|c|}
\hline \multirow[b]{2}{*}{ Categories } & \multirow[b]{2}{*}{$n$} & \multicolumn{2}{|c|}{ Proteins } & \multirow[b]{2}{*}{$P$} & \multirow[b]{2}{*}{$n$} & \multicolumn{2}{|c|}{ Fibre $(\mathrm{g})$} & \multirow[b]{2}{*}{$P$} & \multirow[b]{2}{*}{$n$} & \multicolumn{2}{|c|}{$\mathrm{Na}(\mathrm{mg})$} & \multirow[b]{2}{*}{$P$} \\
\hline & & Median & IQR & & & Median & IQR & & & Median & IQR & \\
\hline \multicolumn{13}{|l|}{ Group 1} \\
\hline Without NC & 34 & 9.6 & $6 \cdot 3-14 \cdot 2$ & \multirow[t]{2}{*}{$0.026^{*}$} & 34 & $2 \cdot 0$ & $0.6-5.6$ & \multirow[t]{2}{*}{0.472} & 36 & 22.5 & $0.0-278.4$ & \multirow[t]{2}{*}{$<0.001$} \\
\hline With NC & 36 & $6 \cdot 3$ & $5 \cdot 1-10 \cdot 0$ & & 36 & 2.9 & $0.9-4.3$ & & 36 & $416 \cdot 7$ & $318 \cdot 3-507 \cdot 3$ & \\
\hline \multicolumn{13}{|l|}{ Group 2} \\
\hline Without NC & 7 & 1.0 & $0.9-3.0$ & \multirow{2}{*}{0.377} & 7 & $2 \cdot 6$ & $2 \cdot 5-3.0$ & \multirow{2}{*}{0.377} & 6 & $35 \cdot 2$ & $35 \cdot 0-260 \cdot 0$ & \multirow{2}{*}{0.203} \\
\hline With NC & $1 \dagger$ & 3.0 & - & & $1 \dagger$ & 3.0 & - & & $1 \dagger$ & 433.3 & - & \\
\hline \multicolumn{13}{|l|}{ Group 3} \\
\hline Without NC & $1 \dagger$ & 0.3 & - & \multirow[t]{2}{*}{-} & $1 \dagger$ & $2 \cdot 0$ & - & \multirow[t]{2}{*}{-} & $1 \dagger$ & 1.0 & - & \multirow[t]{2}{*}{0.137} \\
\hline With NC & - & - & & & - & - & & & 5 & 4.2 & $4 \cdot 1-4 \cdot 2$ & \\
\hline \multicolumn{13}{|l|}{ Group 4} \\
\hline Without NC & 22 & $2 \cdot 4$ & $2.0-3 \cdot 4$ & \multirow[t]{2}{*}{0.667} & 13 & 0.0 & $0.0-0.5$ & \multirow{2}{*}{$<0.001^{*}$} & 25 & $54 \cdot 7$ & $40 \cdot 0-114 \cdot 6$ & \multirow[t]{2}{*}{$0.008^{*}$} \\
\hline With NC & 38 & $2 \cdot 3$ & $2 \cdot 1-6 \cdot 2$ & & 29 & 0.0 & $0.0-0.0$ & & 38 & $40 \cdot 2$ & $35 \cdot 0-53 \cdot 3$ & \\
\hline \multicolumn{13}{|l|}{ Group 5} \\
\hline Without NC & 9 & $12 \cdot 0$ & $12 \cdot 0-12 \cdot 3$ & \multirow{2}{*}{0.235} & 8 & 0.0 & $0.0-1.6$ & \multirow[t]{2}{*}{0.215} & 9 & $346 \cdot 1$ & $120.0-777.5$ & \multirow[t]{2}{*}{0.487} \\
\hline With NC & 14 & $12 \cdot 3$ & $12 \cdot 0-13 \cdot 1$ & & 14 & 1.5 & $0.0-1.8$ & & 14 & 534.3 & $367 \cdot 7-622 \cdot 0$ & \\
\hline Group 6 & & & & & & & & & & & & \\
\hline Without NC & 7 & $5 \cdot 8$ & $0.0-15 \cdot 0$ & 0.234 & 7 & 3.7 & $0.0-6.7$ & 0.235 & 6 & $91 \cdot 7$ & $0.0-650.0$ & 0.709 \\
\hline With NC & 5 & 0.0 & $0.0-5 \cdot 8$ & & 5 & 0.0 & $0.0-0.0$ & & 5 & $600 \cdot 0$ & $91 \cdot 7-600 \cdot 0$ & \\
\hline Group 7 & & & & & & & & & & & & \\
\hline Without NC & 96 & 5.4 & $2 \cdot 3-6 \cdot 9$ & $0.027^{*}$ & 83 & 0.8 & $0.0-2 \cdot 7$ & 0.594 & 118 & $52 \cdot 7$ & $7 \cdot 2-124 \cdot 0$ & $<0.001^{\star}$ \\
\hline With NC & 139 & $5 \cdot 7$ & $4 \cdot 3-8 \cdot 0$ & & 117 & 1.0 & $0.0-2 \cdot 3$ & & 157 & $225 \cdot 0$ & $96 \cdot 2-516 \cdot 7$ & \\
\hline Group 8 & & & & & & & & & & & & \\
\hline Without NC & 33 & 7.4 & $6 \cdot 1-10 \cdot 6$ & 0.487 & 33 & 1.6 & $1.0-2.5$ & 0.097 & 34 & 392.6 & $345 \cdot 6-502 \cdot 5$ & $0.001^{*}$ \\
\hline With NC & 7 & 9.4 & $8 \cdot 7-9.8$ & & 7 & $2 \cdot 4$ & $1 \cdot 9-2 \cdot 8$ & & 7 & 1720.0 & $1596 \cdot 5-1778.8$ & \\
\hline
\end{tabular}

NC, nutrient claim; Group 1, baking goods, breads, cereals, legumes, roots, tubers and related products; Group 2, fresh and canned vegetables; Group 3, fruits, juices, syrups and drink mix; Group 4, milk and dairy products; Group 5 , meats and eggs; Group 6, oils, fats and nuts; Group 7, sugars and products in which carbohydrates and fats are the main energy sources; Group 8, gravies, sauces, ready-made seasonings, broths and ready-to-eat dishes.

† The IQR were run for all groups, except for groups with only one food product. 
without nutrient claims), higher carbohydrate $(60.6 \mathrm{~g} / 100 \mathrm{~g}$ compared with $13.0 \mathrm{~g} / 100 \mathrm{~g}$ in those without nutrient claims), higher total fat $(17.9 \mathrm{~g} / 100 \mathrm{~g}$ compared with $8.0 \mathrm{~g} / 100 \mathrm{~g}$ in those without nutrient claims) and higher SFA ( $8.0 \mathrm{~g} / 100 \mathrm{~g}$ compared with $3.4 \mathrm{~g} / 100 \mathrm{~g}$ in those without nutrient claims), in addition to the differences in $\mathrm{Na}$ highlighted above, compared with food products without nutrient claims.

In addition, children's food products in Group 1 with nutrient claims stated lower levels of protein than those without nutrient claims, whereas the opposite applied to products in Group 7. Differences were also observed among the food products in Group 5 ('meats and eggs'), in which products without nutrient claims had higher levels of SFA. In Group 4, despite food products with nutrient claims that had lower levels of fibre, a caveat must be stated regarding this difference. Significance was due to the fact that values of $25 \%$ of food products without claims were different from 0 . The median for food products with and without nutrient claims, however, was the same, indicating that the difference applied to less than half of the products

\section{Discussion}

This study presents the analyses of all food products targeted at children available in one of the largest supermarket chain stores in Brazil, in which more than 5000 products were investigated regarding the presence of marketing strategies to target children, and subsequently related to their nutrient claims and nutritional composition.

Almost $10 \%$ ( $n$ 535) of all food products available in the supermarket used a marketing strategy specifically targeted at children, mainly involving the presence of images - either well-known TV characters or the brands' own characters. Moreover, more than half of these products essentially comprised chocolate drinks, confectionery, sweet biscuits, crisps and carbonated drinks. Only $3 \%$ of food products targeted at children were from Groups 2 and 3 (vegetables and fruits).

The results are in alignment with findings showing that the food and drink marketing industry aimed at children is substantial and mainly promotes pre-sugared breakfast cereals, soft drinks, savoury snacks, confectionery and fast foods. Packaging routinely attracts children's attention, and stimulates acceptance, liking of and demand for products ${ }^{(22)}$. Moreover, a Canadian study that investigated regular foods targeted at children and their nutritional composition found that only around $1 \%$ of their sample was represented by fruits and vegetables. According to the authors, children's fare in the world of fresh produce is restricted to 'small apples and baby carrots' ${ }^{(34)}$. Our study also showed that fruits and vegetables still are much deprecated categories related to marketing use for children.

Our general outcomes indicating the nutritional composition of food products with and without claims were reasonably similar, except for $\mathrm{Na}$ content. These findings are similar to the results of a study conducted in the USA, which investigated the nutritional quality of children's breakfast cereals. Although specific claims on packages were generally justified by the nutritional content of the product (e.g. children's cereals with claims about whole grains had higher fibre content - one of the benefits of whole grains), cereals with such claims did not have better overall nutrition profiles ${ }^{(30)}$.

Some may argue that modifying components in product formulations could be related to a slight benefit associated with the nutrient/ingredient linked to the claim - for instance, a reduction in salt levels or SFA. However, about $85 \%$ of the nutrient claims found in this study related to the presence, or increased amounts, of vitamins and minerals. Authors have expressed their concern about this kind of modification of foods ${ }^{(37)}$, both because of the levels of these micronutrients that are actually utilised by the human body and also because of the high level of processing that these foods undergo. Moreover, it is quite concerning from a public health point of view that processed and ultra-processed food products are seen as vitamin and mineral providers - a role that should be played by the intake of fresh fruits and vegetables.

Furthermore, processed food products are an important source of $\mathrm{Na}$ in the diet, and the increased consumption of these products has become a public health problem owing to their high $\mathrm{Na}$ content ${ }^{(38)}$, which relates to an increased risk of developing noncommunicable diseases ${ }^{(39)}$. A study that assessed the Na content reported on the labels of foods sold in Brazil and usually consumed as snacks by children and adolescents found that $56 \cdot 0 \%$ had medium-to-high ( $>120 \mathrm{mg} / 100 \mathrm{~g}$ ) Na content, and that $53.0 \%$ of the ready-to-eat dishes were classified as high in $\mathrm{Na}$ (>600 mg/ $100 \mathrm{~g})^{(40)}$. The higher amounts of $\mathrm{Na}$ found in claim-carrying food products' labels, such as bread, confectioneries and pizza, were considered particularly important in light of the possibility of the bealth halo effect caused by the nutrient claim.

In addition to the higher amounts of $\mathrm{Na}$, food products with nutrient claims from Group 8 (i.e. ketchup, lasagne, salt dough pie, pizza, noodles) also showed higher quantities of energy content, carbohydrates and total and SFA than products without claims. It is known that the atherogenic process starts in childhood $^{(41)}$, and it has been reported that children have been consuming higher quantities of SFA than recommended ${ }^{(42)}$. In addition, these food products from Group 8 are defined by the recently published NOVA classification as ultra-processed formulations made by the food industry mostly from substances extracted from foods or obtained from the further processing of constituents of foods or through chemical synthesis, with little if any whole foods. Compared with the rest of the diet, these formulations have less fibre and protein, more added sugar and, when solid, higher energy density ${ }^{(43)}$. A population-based study conducted with 30243 Brazilian individuals aged $\geq 10$ years evaluated the relationship between consumption of ultra-processed foods and obesity indicators. Those in the highest quintile of consumption of ultra-processed foods had significantly higher BMI and higher odds of being obese and have excess weight compared with those in the lowest quintile of consumption ${ }^{(44)}$.

Studies from different countries have indicated that children's products with claims are generally 'less-healthy'. In the USA, the study by Colby et $a l .{ }^{(45)}$ found that $71.0 \%$ of products marketed for children had nutrition marketing (including nutrient claims), 
and $59.0 \%$ of those were high in SFA, Na and/or sugar. A study conducted in a major supermarket chain in South Australia found that $75.0 \%$ of food and beverage products marketed for children were non-core foods (i.e. high in fat and sugar according to the Australian Guide to Healthy Eating), $55.5 \%$ of which had nutrition claims ${ }^{(46)}$. In Guatemala, a study investigated child-oriented snacks in stores inside and near four schools in an urban community and classified $97.1 \%$ of the snacks as 'less-healthy'. Nutrient claims were present in $41 \%$ of them ${ }^{(47)}$. Likewise, a study in New Zealand found a greater proportion of nutrition claims among 'less healthy' cereals for kids than in the 'healthy' category ${ }^{(48)}$.

Although most of the food products targeted at children belonged to Group 7 - presumably unhealthy - it is not possible to affirm that the quantities of the components of these foods were inappropriate. This aspect was not explored in this study because Brazil does not have a nutrient profile system to evaluate the composition of food targeted at children. Therefore, it would be necessary to apply an international nutrient profile model used to limit food marketing aimed at children, and try to adapt it to the Brazilian scenario. These analytical methods are under construction by our group. We believe that, to prevent comparative misleading claims on packaging, the regulations on the use of nutrient claims should be revised, so that only products with appropriate nutrient profiles should be allowed to display nutrient claims.

As a limitation of this study, we highlight the difficulty of classifying certain packaged foods not covered by Regulation no. 359/2003, such as hydroponic and lyophilised vegetables, not common in Brazil when the Regulation was implemented $^{(33)}$. In addition, the circumstance of working with only one supermarket has to be considered. Nevertheless, care was taken in selecting the supermarket in order that our database would consist of products that could be found in any other part of the country, pertaining to brands sold throughout the territory. Moreover, we believe that this is the third survey in Brazil investigating aspects of all food product labels within a single supermarket; the other two studies were conducted by our research group in other large supermarkets. In 2010, one study focused on how trans-fat is reported on the packaging of foods sold in Brazil, and in 2011 another study investigated the relationship between serving sizes and the $\mathrm{Na}$ content of processed and ultra-processed food products.

As avenues for future research, we indicate the need to analyse Brazilian consumers' perceptions about products with nutrition claims targeted at children and investigate the consumption of such products by Brazilian youngsters.

\section{Conclusions}

The data presented here show a broad picture regarding the use of nutrient claims on food products targeted at children in Brazil. The nutritional composition of the food products with and without claims was reasonably similar except for the $\mathrm{Na}$ content, which was found to be in higher quantities in food products displaying nutrient claims. Therefore, nutritional claims may be misleading consumers into thinking that the products are healthy choices overall, which was not observed in this study.

As previously discussed, this is of even more concern in food products targeted at children. Hence, the authors believe that it is necessary to establish thresholds for certain dietary components such as energy, $\mathrm{Na}$, sugar and total and SFA in order to use claims in a more appropriate way, as well as to investigate the views and behaviour of Brazilian parents regarding the presence of nutrient claims on food targeted at their children.

This investigation is an important step in the discussion about the necessity of restricting nutrient claims for certain categories of food, as well as about strategies to present clearer information that could help consumers make more informed choices. These data could support regulatory actions for the greater protection of consumer rights, which would enhance consumer autonomy and minimise misinterpretations. In addition, we believe such actions could contribute to preventing the burden of overweight and obesity among Brazilian children, who will soon turn into adolescents and after that reach the work force where weight and health status will impact economic power.

\section{Acknowledgements}

The authors thank the Federal Agency for Support and Evaluation of Graduate Education in Brazil - CAPES, for their financial support in the form of scholarships to V. M. R., A. C. F. and R. C. d. O.

This analysis was conducted as part of a wider study about the comprehension and use of food labelling in Brazil, funded by the National Council for Scientific and Technological Development of the Ministry of Science and Technology in Brazil (CNPq) and by the Brazilian Health Surveillance Agency, Anvisa (grant no. 440040/2014-0), with the aim of filling gaps relating to the policies, management and organisation of the Brazilian National Health Surveillance System.

V. M. R. was responsible for planning the research, as well as for drafting the manuscript. V. M. R., A. C. F. and R. C. d. O. contributed to collecting, analysing and interpreting the data. A. C. F. and R. C. d. O. contributed to revising the manuscript. R. P. d. C. P. and M. R. contributed to data analysis, interpretation of results and revision of the manuscript. G. M. R. F. was responsible for the design of the original study, research coordination, supervision and revision of the final manuscript. All the authors approved this version for publication and accepted the conditions established by the British Journal of Nutrition.

The authors declare that they have no conflicts of interest.

\section{References}

1. Monteiro CA, Gomes FS \& Cannon G (2010) The snack attack. Am J Public Health 100, 975-981.

2. Conde WL \& Monteiro CA (2014) Nutrition transition and double burden of undernutrition and excess of weight in Brazil. Am J Clin Nutr 100, 1617-1622.

3. Brazilian Institute of Geography and Statistics (IBGE) (2014) National Survey of Health 2013 - PNS 2013. Perceived Health Status, Lifestyles and Chronic Diseases Brazil, Major Regions and Federation Units. Rio de Janeiro: IBGE. 
4. Brazilian Institute of Geography and Statistics (IBGE) (2010) Consumer Expenditure Survey - POF 2008-2009. Anthropometry and Nutritional Status of Children, Teenagers and Adults in Brazil. Rio de Janeiro: IBGE.

5. Ng M, Fleming T, Robinson M, et al. (2013) Global, regional, and national prevalence of overweight and obesity in children and adults during 1980-2013: a systematic analysis for the Global Burden of Disease Study 2013. Lancet 384, 766-781.

6. Rtveladze K, Marsh T, Webber L, et al. (2013) Health and economic burden of obesity in Brazil. PLOS ONE 8, e68785.

7. World Health Organization (2013) Global Action Plan for the Prevention and Control of Noncommunicable Diseases 2013-2020. Geneva: WHO.

8. World Health Organization (2007) Codex Alimentarius. Joint WHO/FAO. Food Labelling, 5th ed. Rome: Codex Alimentarius Commission.

9. Post RE, Mainous AG, Diaz VA, et al. (2010) Use of the nutrition facts label in chronic disease management: results from the national health and nutrition examination survey. J Am Diet Assoc 110, 628-632.

10. Muller LM, Cassady DL, Applegate EA, et al. (2015) Relationships among food label use, motivation, and dietary quality. Nutrients 7, 1068-1080.

11. Cowburn G \& Stockley L (2005) Consumer understanding and use of nutrition labelling: a systematic review. Public Health Nutr 8, 21-28.

12. Grunert KG \& Wills JM (2007) A review of European research on consumer response to nutrition information on food labels. J Public Health 15, 385-399.

13. Rayner M, Wood A, Lawrence M, et al. (2013) Monitoring the health-related labelling of foods and non-alcoholic beverages in retail settings. Obes Rev 14, Suppl. 1, S70-S81.

14. Campos S, Doxey J \& Hammond D (2011) Nutrition labels on pre-packaged foods: a systematic review. Public Health Nutr 14, 496-1506.

15. European Food Information Council (2015) Global update on nutrition labelling. Produced in collaboration with Landmark. European Food Information Council, January. http://www. eufic.org/upl/1/default/doc/GlobalUpdateExecSumJan2015.pdf (accessed August 2015).

16. National Health Surveillance Agency (BR) (2012) Resolution RDC n 54, of November 12, 2012 (Provides the Technical Regulation on Nutrient Claims, 2012). Federal Employee Gazette, 13 November 2012. ftp://ftp.saude.sp.gov.br/ftpsessp/ bibliote/informe_eletronico/2012/iels.nov.12/Iels215/U_RS-MSANVISA-RDC-54_121112.pdf (accessed March 2016).

17. United States Department of Health and Human Services (2013) Code of Federal Regulations. Nutrient content claims general principles. 21 CFR 101.13. Revised as of 1 April 2012. http://www.accessdata.fda.gov/scripts/cdrh/cfdocs/cfcfr/CFR Search.cfm?fr=101.13\&SearchTerm $=$ nutrient (accessed August 2013).

18. Food Standards Australia New Zealand (2013) Australia New Zealand food standards code-standard 1.2.7. nutrition, health and related claims. F2014C01191. Registered 15 January 2013, Australian Government. https://www.comlaw.gov.au/Details/ F2014C01191 (accessed August 2015).

19. European Commission (2015) Food. Labelling and nutrition. Health and nutrition claim. Nutrition and health claims. http:// ec.europa.eu/food/food/labellingnutrition/claims/index_en.htm (accessed August 2015).

20. Hawkes C (2004) Nutrition Labels and Health Claims: The Global Regulatory Environment. Geneva: WHO.

21. Chandon P (2013) How package design and packaged-based marketing claims lead to overeating. Appl Econ Perspect Policy 35, 7-31.
22. Cairns G, Angus K, Hastings G, et al. (2013) Systematic reviews of the evidence on the nature, extent and effects of food marketing to children. a retrospective summary. Appetite 62, 209-215.

23. Nestle M \& Ludwig D (2010) Front-of-package food labels: public health or propaganda? JAMA 303, 771-772.

24. Legault L, Brandt MB, Mccabe N, et al. (2004) 2000-2001 food label and package survey: an update on prevalence of nutrition labeling and claims on processed, packaged foods. J Am Diet Assoc 104, 952-958.

25. Williams P, Yeatman H, Zakrzewski S, et al. (2003) Nutrition and related claims used on packaged Australian foods implications for regulation. Asia Pac J Clin Nutr 12, 138-150.

26. Ten JA, Olalla MC \& Torres AH (2007) A review of nutrition and health claims in food. Rev Esp Nutr Comunitaria 13, 163-175.

27. Söyler G \& El SN (2009) Investigation on Turkish consumers regarding their attitudes towards grammatical styles, knowledge and compliance of nutrition messages. Nutr Food Sci 39, 520-533.

28. Lalor F, Kennedy J, Flynn MAT, et al. (2009) A study of nutrition and health claims - a snapshot of what's on the Irish market. Public Health Nutr 13, 704-711.

29. Kaur A, Scarborough P, Matthews A, et al. (2015) How many foods in the UK carry health and nutrition claims, and are they healthier than those that do not? Public Health Nutr 8, 1-10.

30. Schwartz MB, Vartanian LR, Wharton CM, et al. (2008) Examining the nutritional quality of breakfast cereals marketed to children. J Am Diet Assoc 108, 702-705.

31. Lythgoe A, Roberts C, Madden AM, et al. (2013) Marketing foods to children: a comparison of nutrient content between children's and non-children's products. Public Health Nutr 16, 2221-2230.

32. Ministry of Health, Brazilian Health Surveillance Agency (Anvisa) (2003) Resolution - RDC n. 360, of December 23, 2003 (Approves the technical rules for packaged food labelling, and become it mandatory). Federal Employee Gazette, 24 December. Federal Employee Gazette, 23 December 2003. http://portal.anvisa.gov.br/wps/wcm/connect/ec3966804ac02 cf1962abfa337abae9d/Resolucao_RDC_n_360de_23_de_ dezembro_de_2003.pdf?MOD=AJPERES (accessed March 2016).

33. Ministry of Health, Brazilian Health Surveillance Agency (Anvisa) (2003) Resolution - RDC n. 359, of December 23, 2003 (Approves the technical rules for packaged food serving sizes for purposes of food labelling). Federal Employee Gazette of 24 December. Federal Employee Gazette, 23 December 2003. http://portal.anvisa.gov.br/wps/wcm/connect/ d12c9e804745947f9bf0df3fbc4c6735/RDC_359.pdf?MOD= AJPERES. (accessed March 2016).

34. Elliott C (2008) Assessing 'fun foods': nutritional content and analysis of supermarket foods targeted at children. Obes Rev $\mathbf{9}$, 368-377.

35. Schwartz MB, Vartanian LR, Wharton CM, et al. (2008) Examining the nutritional quality of breakfast cereals marketed to children. J Am Diet Assoc 108, 702-705.

36. Hawkes C (2010) Food packaging: the medium is the message. Public Health Nutr 13, 297-299.

37. Monteiro CA (2009) Nutrition and health. the issue is not food, nor nutrients, so much as processing. Public Health Nutr 12, 729-731.

38. Brown IJ, Tzoulaki I, Candeias V, et al. (2009) Salt intakes around the world: implications for public health. Int J Epidemiol 38, 791-813.

39. World Health Organization (2007) Reducing salt intake in populations, Report, WHO Forum and Technical Meeting, WHO. 5-7 October 2006, Paris, France. http://www.who.int/dietphysi calactivity/Salt_Report_VC_april07.pdf (accessed May 2011). 
40. Kraemer MVS, Oliveira RC, Gonzalez-Chica DA, et al. (2015) Sodium content on processed foods for snacks. Public Health Nutr 9, 1-9.

41. McGill HC Jr, McMahan CA, Herderick EE, et al. (2000) Origin of atherosclerosis in childhood and adolescence. Am J Clin Nutr 72, Suppl. 5, 1307S-1315S.

42. Harika RK, Cosgrove MC, Osendarp SJM, et al. (2011) Fatty acid intakes of children and adolescents are not in line with the dietary intake recommendations for future cardiovascular health: a systematic review of dietary intake data from thirty countries. Br J Nutr 106, 307-316.

43. Monteiro CA, Levy RB, Claro RM, et al. (2011) Increasing consumption of ultra-processed foods and likely impact on human health: evidence from Brazil. Public Health Nutr 14, 5-13.
44. Louzada MLC, Baraldi LG, Steele EM, et al. (2015) Consumption of ultra-processed foods and obesity in Brazilian adolescents and adults. Prev Med 81, 9-15.

45. Colby SE, Johnson L, Scheett A, et al. (2010) Nutrition marketing on food labels. $J$ Nutr Educ Behav 42, 92-98.

46. Mehta K, Phillips C, Ward P, et al. (2012) Marketing foods to children through product packaging: prolific, unhealthy and misleading. Public Health Nutr 15, 1763-1770.

47. Chacon V, Letona P \& Barnoya J (2013) Child-oriented marketing techniques in snack food packages in Guatemala. BMC Public Health 13, 967.

48. Devi A, Eyles H, Rayner M, et al. (2014) Nutritional quality, labelling and promotion of breakfast cereals on the New Zealand market. Appetite 81, 253-260. 